\title{
Nanotitanium dioxide toxicity in mouse lung is reduced in sanding dust from paint
}

\author{
Anne Thoustrup Saber ${ }^{1 *}$, Nicklas Raun Jacobsen', Alicia Mortensen², Józef Szarek³, Petra Jackson', \\ Anne Mette Madsen ${ }^{1}$, Keld Alstrup Jensen ${ }^{1}$, Ismo K Koponen ${ }^{1}$, Gunnar Brunborg ${ }^{6}$, Kristine Bjerve Gützkow ${ }^{6}$, \\ Ulla Vogel ${ }^{1,4}$ and Håkan Wallin ${ }^{1,5}$
}

\begin{abstract}
Background: Little is known of how the toxicity of nanoparticles is affected by the incorporation in complex matrices. We compared the toxic effects of the titanium dioxide nanoparticle UV-Titan L181 $\left(\mathrm{NanOTiO}_{2}\right)$, pure or embedded in a paint matrix. We also compared the effects of the same paint with and without $\mathrm{NanoTiO}_{2}$.

Methods: Mice received a single intratracheal instillation of 18,54 and $162 \mu \mathrm{g}$ of $\mathrm{NanoTiO}_{2}$ or 54, 162 and $486 \mu \mathrm{g}$ of the sanding dust from paint with and without $\mathrm{NanoTiO}_{2}$. DNA damage in broncheoalveolar lavage cells and liver, lung inflammation and liver histology were evaluated 1, 3 and 28 days after intratracheal instillation. Printex 90 was included as positive control.

Results: There was no additive effect of adding $\mathrm{NanoTiO}_{2}$ to paints: Therefore the toxicity of $\mathrm{NanoTiO}_{2}$ was reduced by inclusion into a paint matrix. $\mathrm{NanoTiO}_{2}$ induced inflammation in mice with severity similar to Printex 90. The inflammatory response of $\mathrm{NanoTiO}_{2}$ and Printex 90 correlated with the instilled surface area. None of the materials, except of Printex 90, induced DNA damage in lung lining fluid cells. The highest dose of $\mathrm{NanoTiO}_{2}$ caused DNA damage in hepatic tissue 1 day after intratracheal instillation. Exposure of mice to the dust from paints with and without $\mathrm{TiO}_{2}$ was not associated with hepatic histopathological changes. Exposure to $\mathrm{NanoTiO}_{2}$ or to Printex 90 caused slight histopathological changes in the liver in some of the mice at different time points.

Conclusions: Pulmonary inflammation and DNA damage and hepatic histopathology were not changed in mice instilled with sanding dust from $\mathrm{NanoTiO}_{2}$ paint compared to paint without $\mathrm{NanoTiO}_{2}$. However, pure $\mathrm{NanoTiO}_{2}$ caused greater inflammation than $\mathrm{NanoTiO}_{2}$ embedded in the paint matrix.
\end{abstract}

Keywords: Nanoparticles, Nano titanium dioxide, UV-Titan L181, sanding dusts, paint matrix, inflammation, DNA damage, liver histology

\section{Background}

Paints and lacquers represent a product group in which nanomaterials are increasingly used due to improvement of characteristics of the products [1]. One example is the addition of nanosized titaniumdioxide $\left(\mathrm{TiO}_{2}\right)$ to paints [1]. Whereas bulk sized $\mathrm{TiO}_{2}$ has been used for decades as a whitening agent in paints, nanosized $\mathrm{TiO}_{2}$ is added to paints for example as UV-filters or to improve their rheology, for providing self-cleaning properties or for removing odours from air [1]. It is

\footnotetext{
* Correspondence: ats@nrcwe.dk

${ }^{1}$ The National Research Centre for the Working Environment, Lers $\varnothing$ Parkallé 105, DK-2100 Copenhagen, Denmark

Full list of author information is available at the end of the article
}

estimated that the global use of $\mathrm{TiO}_{2}$ for paint and surface applications exceeds 2.5 million tonnes annually (2005) [2].

Some $\mathrm{TiO}_{2}$ nanoparticles have been shown to have inflammogenic, oxidative, and genotoxic effects (reviewed in [3]). Recently, IARC classified $\mathrm{TiO}_{2}$ as possibly carcinogenic to humans (Group 2B). This was based on an evaluation showing sufficient evidence of carcinogenicity in experimental animals and inadequate evidence for human carcinogenicity [2].

Whereas exposure may occur during handling and use of freely dispersed nanomaterials $[4,5]$, very little is known of the emissions of nanomaterials during the life cycle (e.g., finishing, sanding, abrasion, weathering and

\section{( Biomed Central}


incineration) of products containing nanomaterials [6-10]. There are also much more data on the adverse effects of pure nanomaterials [11], but almost nothing is known on the toxicity of nanoparticles incorporporated into matrices such as paints and plastics $[6,12,13]$.

We have previously characterised the dust obtained from sanding wooden boards painted with different types of paints or lacquers with and without nanoparticles [7]. Sanding generated both nano- and micrometer-sized particles. Sanding of some of the nanoparticle containing paints led to increased formation of nanosized particles compared to the reference paint, but there was no consistent pattern in which paints gave rise to increased formation of nanosized sanding particles, nor the amount [7]. We have screened the toxicity of the pure nanomaterials [14] and of the sanding dust in mice using a single dose $(54 \mu \mathrm{g})$ and a single time point after intratracheal instillation (1 day) [12]

Based on this screening $[12,14]$, we selected sanding dusts from a conventional indoor paint with and without $\mathrm{NanoTiO}_{2}$ (Indoor-NanoTiO 2 and Indoor-R, respectively) and the same nanosized $\mathrm{TiO}_{2}$ as the one included in the paint $\left(\mathrm{NanoTiO}_{2}\right.$, UV-Titan L181) which induced inflammation and DNA damage. The purpose of the present study was to test the toxicity, by inflammatory and DNA damaging effects, of the materials for doseresponses at different time points. The carbon black type Printex 90 was included as a positive control because we have previously shown that Printex 90 is a potent ROS producer [15] that causes both inflammation, DNA strand breaks and mutations [16].

We evaluated the inflammatory response by characterizing the presence of inflammatory cells in lung fluids. The fibrotic response was analysed by measuring mRNA expression of Tgf-beta because some nanomaterials have been shown to induce fibrosis [17]. DNA damage was analysed by measuring DNA strand breaks in broncheoalveolar lavage cells and liver tissue by the Comet assay as a sensitive assay for genotoxicity.

\section{Results}

Physicochemical characterization of particles

The Danish paint and lacquer industry provided an indoor acrylic paint product with $10 \%$ content of Nano$\mathrm{TiO}_{2}$ (referred as Indoor-NanoTiO${ }_{2}$ ) and a corresponding product without nanomaterials (referred to as Indoor R) (Table 1). The tested pure nanomaterials included a nanosized $\mathrm{TiO}_{2}$ material (UV-Titan L181, code: $\mathrm{NanoTiO}_{2}$ ), and carbon black (Printex 90), which was used as an internal reference particle. Physicochemical characteristics of the particles and the dusts used in the study are presented in detail in our three recent publications $[7,12,14]$.
Table 1 Composition of paints ${ }^{a}$

\begin{tabular}{lccc}
\hline & $\begin{array}{c}\text { Type of } \\
\mathbf{T i O}_{\mathbf{2}}\end{array}$ & $\begin{array}{c}\text { Indoor- } \\
\mathbf{R}^{\mathbf{b}}\end{array}$ & $\begin{array}{c}\text { Indoor- } \\
\text { NanoTiO }_{\mathbf{2}}{ }^{\mathbf{c}}\end{array}$ \\
\hline Water & 15 & 15 \\
Natrosol 250 HR & 0.23 & 0.23 \\
Dispex 40 & 0.56 & 0.56 \\
Proxel B D 20 & & 0.23 & 0.23 \\
Propylenglycole & NanoTiO $_{2}$ & 0 & 6.8 \\
UV-Titan L181 & PigmentTiO $_{2}$ & 23.8 & 10 \\
Tronox R-KB-2 & & 49.8 & 13.8 \\
Plextol D510 & 1.75 & 49.8 \\
Carnauba & & 1.75 \\
waxemulsion20\% & & \\
Butyldiglycole & & 1.31 & 1.31 \\
Collacral 8503 & & 0.13 & 0.13 \\
Dehydran 1227 & 0.17 & 0.17 \\
Ammonia water 24\% & & 0.22 & 0.22 \\
\hline Total & & 100 & 100 \\
\hline
\end{tabular}

${ }^{a}$ Numbers are given in mass \% of total. ${ }^{\mathrm{b}}$ Indoor-R: Indoor paint without $\mathrm{NanoTiO}_{2} \mathrm{C}_{\text {Indoor-NanoTiO }}$ : Indoor paint with $\mathrm{NanoTiO}_{2}$

In brief, the UV-Titan L181 $\left(\mathrm{NanoTiO}_{2}\right)$ was a rutile coated with $\mathrm{Si}, \mathrm{Al}, \mathrm{Zr}$ and polyalcohol [14]. The average crystallite size was determined to be $20.6 \mathrm{~nm}$ and the powder had a specific surface area of $107.7 \mathrm{~m}^{2} / \mathrm{g}$. By electron microscopy of the particle suspensions used for instillation, the primary particles occured in open to dense aggregates of ca. $100 \mathrm{~nm}$ or larger. Printex 90 consisted of small to very large aggregates of primary carbonaceous spheres [14]. The specific surface area was on the order of $295-338 \mathrm{~m}^{2} / \mathrm{g}$. The primary particle size is reported to be $14 \mathrm{~nm}$ by the manufacturer, but has a wide size-range. In the dispersion mediums the aggregate size varied from less than $100 \mathrm{~nm}$ into the micrometer-range. The typical aggregate size was ca. $200 \mathrm{~nm}$.

The collected sanding dusts (Indoor-R and Indoor$\mathrm{NanoTiO}_{2}$ ) were in the respirable size fraction [7]. In both cases the airborne dust could be resolved into five size-modes ranging from ca. $10 \mathrm{~nm}$ to ca. $1.7 \mu \mathrm{m}$. The two smallest modes at ca. 10 and $12.7 \mathrm{~nm}$ mainly if not completely originated from the sanding machine. However, as shown in Sharma et al. [18], the collection efficiency of the electrostatic precipitator rapidly decreases for particles smaller than ca. $30 \mathrm{~nm}$ reducing the importance of these particles in the sampled test materials. We have reported that the coarse particles were dominated by paint aggregates whereas the smaller particles to greater extent consisted of free to aggregated pigments and smaller paint aggregates as determined by scanning electron microscopy [14].

The endotoxin content in supernatants from particle suspensions was assessed using the Limulus Amebocyte lysate enzyme assay (LAL). The endotoxin contents measured in the $4.05 \mathrm{mg} / \mathrm{ml}$ particle suspensions were: 
$0.012 \mathrm{ng} / \mathrm{ml}(0.19 \mathrm{EU} / \mathrm{ml})$ for $\mathrm{NanoTiO}_{2}$ and $0.011 \mathrm{ng} /$ $\mathrm{ml}(0.17 \mathrm{EU} / \mathrm{ml})$ for Printex 90 . The contents of the two dust suspensions were $0.16 \mathrm{ng} / \mathrm{ml}(2.43 \mathrm{EU} / \mathrm{ml})$ for Indoor-NanoTiO $\mathrm{Ni}_{2}$ and $0.024 \mathrm{ng} / \mathrm{ml}(0.36 \mathrm{EU} / \mathrm{ml})$ for Indoor- $\mathrm{R}$. The amount of endotoxin received by mice given the $162 \mu \mathrm{g}$ dose was for all the tested particles and dusts below $0.1 \mathrm{EU}$, a dose equivalent to $6 \mathrm{pg}$ endotoxin, or $0.3 \mathrm{ng}$ endotoxin $/ \mathrm{kg}$ body weight.

\section{Cell count in broncho-alveolar lavage fluid}

To assess the recruitment of inflammatory cells into the lung lumen, we determined the total number of BAL cells and the number of macrophages, neutrophils, eosinophils and lymphocytes in the BAL cells (Table 2). The neutrophil influx is also shown in Figure 1. Data from the control group and the Printex 90 exposed mice have been published elsewhere [19].

The total number of BAL cells was not significantly higher in mice exposed to $18 \mu \mathrm{g}$ of $\mathrm{NanoTiO}_{2}$ and 54 $\mu \mathrm{g}$ of sanding dusts at any time point, compared with the negative control group (Table 2). In mice exposed to $54 \mu \mathrm{g}$ of $\mathrm{NanoTiO}_{2}$, the total number of BAL cells was only higher 1 day after intratracheal instillation, whereas the total number of BAL cells was significantly higher at all-time points in mice exposed to $162 \mu \mathrm{g}$ of NanoTiO 2 .

In mice exposed to $162 \mu \mathrm{g}$ of Indoor-NanoTiO $\mathrm{Ti}_{2}$, the total number of BAL cells was significantly higher 1 day and 3 days after intratracheal instillation, while this was still present 28 days after instillation in mice exposed to $486 \mu \mathrm{g}$ of Indoor-NanoTiO $\mathrm{Nist}_{2}$ du

In mice exposed to $162 \mu \mathrm{g}$ of Indoor-R dust, the total number of BAL cells was significantly higher 1 day after intratracheal instillation, while this increase was still present 3 days after intratracheal instillation in mice exposed to $486 \mu \mathrm{g}$ of Indoor-R dust.

The neutrophil count was not significantly higher in mice exposed to $18 \mu \mathrm{g}$ of $\mathrm{NanoTiO}_{2}$ at any time point, compared with the negative control group (Figure 1, Table 2). In mice exposed to $54 \mu \mathrm{g}$ of $\mathrm{NanoTiO}_{2}$, the neutrophil count was only significantly higher 1 and 3 days after intratracheal instillation, whereas the neutrophil count was significantly higher at all-time points in mice exposed to $162 \mu \mathrm{g}$ of $\mathrm{NanoTiO}_{2}(162 \mu \mathrm{g})$. However, the increase was moderate after 28 days. As described in [19], neutrophil counts were higher at all doses of Printex 901 and 3 days after intratracheal instillation, while only 54 and $162 \mu \mathrm{g}$ of Printex 90 resulted in increased neutrophil influx 28 days after intratracheal instillation. Sanding dust from both paints resulted in increased neutrophil counts in mice 1 day after intratracheal instillation of 162 and $486 \mu \mathrm{g}$. Exposure to $486 \mu \mathrm{g}$ of both types of sanding dust resulted in increased neutrophil numbers 3 days after intratracheal instillation, while no increased influx of neutrophils were observed 28 days after intratracheal instillation. The neutrophil counts were not different between the NanoTiO 2 containing paint (Indoor-NanoTiO ${ }_{2}$ ) and the reference paint without $\mathrm{NanoTiO}_{2}$ (Indoor-R). Thus, inflammation was observed for all tested materials, although the paint dust with and without nanoparticles was much less inflammogenic than the pure $\mathrm{NanoTiO}_{2}$ at similar mass. One day after intratracheal instillation, $162 \mu \mathrm{g}$ of sanding dust was lowest observed adverse effect level (LOAEL) whereas $54 \mu \mathrm{g}$ was no observed adverse effect level (NOAEL). The corresponding values for instillation of $\mathrm{NanoTiO}_{2}$ were $54 \mu \mathrm{g}$ (LOAEL) and $18 \mu \mathrm{g}$ (NOAEL).

Significantly higher numbers of macrophages were only seen 3 days after intratracheal instillation in mice exposed to Indoor- $\mathrm{NanoTiO}_{2}(162$ and $486 \mu \mathrm{g})$ and Indoor-R $(486 \mu \mathrm{g})$ (Table 2$)$.

Higher numbers of eosinophils were observed in mice instilled with Indoor-Nano $\mathrm{TiO}_{2}$ and Indoor- $\mathrm{R} 1$ day after intratracheal instillation of $486 \mu \mathrm{g}$ and 3 days after intratracheal instillation of 162 and $486 \mu \mathrm{g}$. No eosinophils were detected at any time-point in mice exposed to $\mathrm{NanoTiO}_{2}$. Increased numbers of lymphocytes were detected 3 days after intratracheal instillation in mice exposed to $486 \mu \mathrm{g}$ of Indoor- $\mathrm{NanoTiO}_{2}$ and 162 and $486 \mu \mathrm{g}$ of Indoor-R (Table 2).

The only significant difference between the two paints was an increase $(\sim 1.6$-fold) in the total number of BAL cells in the Indoor-NanoTiO $\mathrm{Ti}_{2}$ exposed mice compared to Indoor-R exposed mice (Table 2).

\section{Tgf- $\beta$ mRNA expression in the lungs}

The pulmonary Tgf- $\beta$ mRNA expression levels were assessed as a marker for a profibrotic response. The Tgf- $\beta$ mRNA expression levels were not affected by any of the tested materials (all doses at all-time points) compared to control mice (results not shown).

\section{DNA damage}

DNA damage was determined in BAL cells (Figure 2) and liver tissue (Figure 3) by the Comet assay.

\section{BAL cells}

Neither the $\mathrm{NanoTiO}_{2}$ nor Indoor- $\mathrm{TiO}_{2}$ and Indoor- $\mathrm{R}$ resulted in significant increases in DNA strand breaks in BAL cells at any of the tested doses and time points. Printex 90 induced a statistically significant increase in DNA strand breaks in the BAL cells 1 day after intratracheal instillation of 18 and $162 \mu \mathrm{g}$ and 28 days after intratracheal instillation of all doses $(18,54,162 \mu \mathrm{g})$, while there was only effect at the $162 \mu \mathrm{g}$ dose 3 days after intratracheal instillation [19]. 
Table 2 BAL fluid counts in mice.

\begin{tabular}{|c|c|c|c|c|c|c|c|c|c|c|c|}
\hline \multirow[b]{2}{*}{1 day } & & \multirow[t]{2}{*}{ Control } & \multicolumn{3}{|c|}{$\mathrm{NanoTiO}_{2}$} & \multicolumn{3}{|c|}{ Indoor-R } & \multicolumn{3}{|c|}{ Indoor-NanoTiO ${ }_{2}$} \\
\hline & & & $18 \mu \mathrm{g}$ & $54 \mu \mathrm{g}$ & $162 \mu \mathrm{g}$ & $54 \mu \mathrm{g}$ & $162 \mu \mathrm{g}$ & $486 \mu \mathrm{g}$ & $54 \mu \mathrm{g}$ & $162 \mu \mathrm{g}$ & $486 \mu \mathrm{g}$ \\
\hline & Neutrophils $\left(\times 10^{3}\right)$ & $7.7 \pm 1.7$ & $4.9 \pm 1.5$ & $56.8 \pm 7.2^{* * *}$ & $189.9 \pm 29.1^{* * *}$ & $14.2 \pm 3.5$ & $61.7 \pm 17.8^{* *}$ & $176.5 \pm 18.8^{* * *}$ & $19.7 \pm 3.5$ & $58.2 \pm 10.5^{* *}$ & $170.4 \pm 25.3^{* * *}$ \\
\hline & Macrophages $\left(\times 10^{3}\right)$ & $53.2 \pm 2.5$ & $64.1 \pm 6.9$ & $56.4 \pm 5.8$ & $41.4 \pm 6.2$ & $61.1 \pm 7.7$ & $69.5 \pm 4.1$ & $78.9 \pm 13.1$ & $73.0 \pm 7.1$ & $68.8 \pm 6.6$ & $51.4 \pm 7.2$ \\
\hline & Eosinophils $\left(\times 10^{3}\right)$ & $0.3 \pm 0.4$ & $0.3 \pm 0.2$ & $1.3 \pm 0.7$ & $2.1 \pm 0.6$ & $0.2 \pm 0.1$ & $2.0 \pm 1.0$ & $20.5 \pm 3.1^{* * *}$ & $0.2 \pm 0.2$ & $1.3 \pm 0.5$ & $10.1 \pm 5.4^{* * *}$ \\
\hline & Lymphocytes $\left(\times 10^{3}\right)$ & $1.6 \pm 0.2$ & $1.2 \pm 0.5$ & $1.0 \pm 0.3$ & $2.4 \pm 1.0$ & $0.7 \pm 0.2$ & $2.1 \pm 0.8$ & $3.4 \pm 1.4$ & $0.9 \pm 0.2$ & $2.2 \pm 0.8$ & $2.7 \pm 1.0$ \\
\hline & Total BAL cells $\left(\times 10^{3}\right)$ & $74.0 \pm 3.6$ & $77.6 \pm 8.8$ & $123 \pm 12.8^{* *}$ & $246.5 \pm 31.1^{* * *}$ & $85.4 \pm 8.2$ & $146.4 \pm 22.1^{* * *}$ & $298.8 \pm 25.5^{* * *}$ & $106.3 \pm 9.5$ & $139.2 \pm 14.2^{* * *}$ & $256.3 \pm 29.5^{* * *}$ \\
\hline \multicolumn{12}{|l|}{3 days } \\
\hline & Neutrophils $\left(\times 10^{3}\right)$ & $3.0 \pm 2.3$ & $0.9 \pm 0.5$ & $6.5 \pm 1.0^{* *}$ & $78.1 \pm 10.5^{* * *}$ & $2.6 \pm 1.9$ & $4.4 \pm 1.6$ & $17.4 \pm 2.7^{* * *}$ & $1.5 \pm 0.5$ & $3.7 \pm 0.9$ & $21.4 \pm 5.3^{* * *}$ \\
\hline & Macrophages $\left(\times 10^{3}\right)$ & $56.4 \pm 4.2$ & $58.9 \pm 8.5$ & $57.3 \pm 6.9$ & $84.2 \pm 0.8$ & $56.5 \pm 6.2$ & $69.7 \pm 6.3$ & $128.9 \pm 8.2^{* * *}$ & $69.2 \pm 7.9$ & $85.6 \pm 5.6^{*}$ & $106.6 \pm 6.8^{* * *}$ \\
\hline & Eosinophils $\left(\times 10^{3}\right)$ & $0.4 \pm 0.6$ & $0.5 \pm 0.2$ & $0.9 \pm 0.3$ & $9.7 \pm 6.5$ & $4.8 \pm 0.4$ & $8.4 \pm 2.2^{* * *}$ & $45.0 \pm 8.3^{* * *}$ & $0.9 \pm 0.3$ & $7.9 \pm 3.8^{* * *}$ & $19.0 \pm 7.5^{* * *}$ \\
\hline & Lymphocytes $\left(\times 10^{3}\right)$ & $0.9 \pm 0.2$ & $0.8 \pm 0.3$ & $0.8 \pm 0.2$ & $4.6 \pm 1.8$ & $1.5 \pm 0.7$ & $6.7 \pm 1.6^{* * *}$ & $14.1 \pm 4.4^{* * *}$ & $1.3 \pm 0.3$ & $2.9 \pm 1.3$ & $8.5 \pm 3.4^{*}$ \\
\hline & Total BAL cells $\left(\times 10^{3}\right)$ & $69.1 \pm 6.4$ & $66.9 \pm 8.6$ & $71.8 \pm 8.3$ & $185.3 \pm 14.0^{* * *}$ & $69.3 \pm 6.6$ & $99.4 \pm 7.6$ & $221.4 \pm 17.2^{* * *}$ & $81.0 \pm 8.2$ & $109.3 \pm 4.8^{* * *}$ & $174.9 \pm 19.4^{* * *}$ \\
\hline \multicolumn{12}{|c|}{28 days } \\
\hline & Neutrophils $\left(\times 10^{3}\right)$ & $1.2 \pm 0.2$ & $1.1 \pm 0.3$ & $2.8 \pm 0.6$ & $14.7 \pm 2.7^{* * *}$ & $0.6 \pm 0.4$ & $1.2 \pm 0.4$ & $1.4 \pm 0.2$ & $1.1 \pm 0.4$ & $1.8 \pm 0.9$ & $6.6 \pm 2.0$ \\
\hline & Macrophages $\left(\times 10^{3}\right)$ & $82.4 \pm 5.7$ & $79.5 \pm 5.4$ & $71.8 \pm 10.7$ & $106.2 \pm 14.6$ & $54.1 \pm 3.6$ & $64.0 \pm 3.6$ & $91.2 \pm 13.3$ & $94.6 \pm 23.5$ & $92.8 \pm 6.1$ & $141.5 \pm 30.4$ \\
\hline & Eosinophils $\left(\times 10^{3}\right)$ & $0.3 \pm 0.0$ & $0.5 \pm 0.5$ & $1.6 \pm 0.0$ & $1.2 \pm 1.1$ & $0.0 \pm 0.0$ & $1.9 \pm 1.5$ & $0.1 \pm 0.1$ & $0.07 \pm 0.07$ & $0.7 \pm 0.6$ & $3.2 \pm 2.9$ \\
\hline & Lymphocytes $\left(\times 10^{3}\right)$ & $2.1 \pm 0.4$ & $2.0 \pm 0.4$ & $3.8 \pm 1.0$ & $18.4 \pm 3.8$ & $1.4 \pm 0.4$ & $2.8 \pm 0.6$ & $5.0 \pm 1.3$ & $2.0 \pm 1.0$ & $1.6 \pm 0.5$ & $5.8 \pm 2.4$ \\
\hline & Total BAL cells $\left(x 10^{3}\right)$ & $95.9 \pm 5.8$ & $94.1 \pm 6.9$ & $85.8 \pm 11.6$ & $154.7 \pm 16.0^{*}$ & $62.5 \pm 3.9$ & $79.5 \pm 4.9$ & $108.8 \pm 13.0$ & $104.6 \pm 25.0^{*}$ & $107.9 \pm 6.0$ & $173.6 \pm 28.6^{* * \#}$ \\
\hline
\end{tabular}

BAL fluid counts in mice. 1, 3 and 28 days post-exposure to $18 \mu \mathrm{g}, 54 \mu \mathrm{g}$ and $162 \mu \mathrm{g}$ NanoTiO2, $54 \mu \mathrm{g}, 162 \mu \mathrm{g}$ and $486 \mu \mathrm{g}$ sanding dusts and control mice. * ******: Statistically significant compared to control mice

at the $0.5,0.01$ and 0.001 level, respectively. \#: Statistically significant difference between the two paints at the 0.05 level 

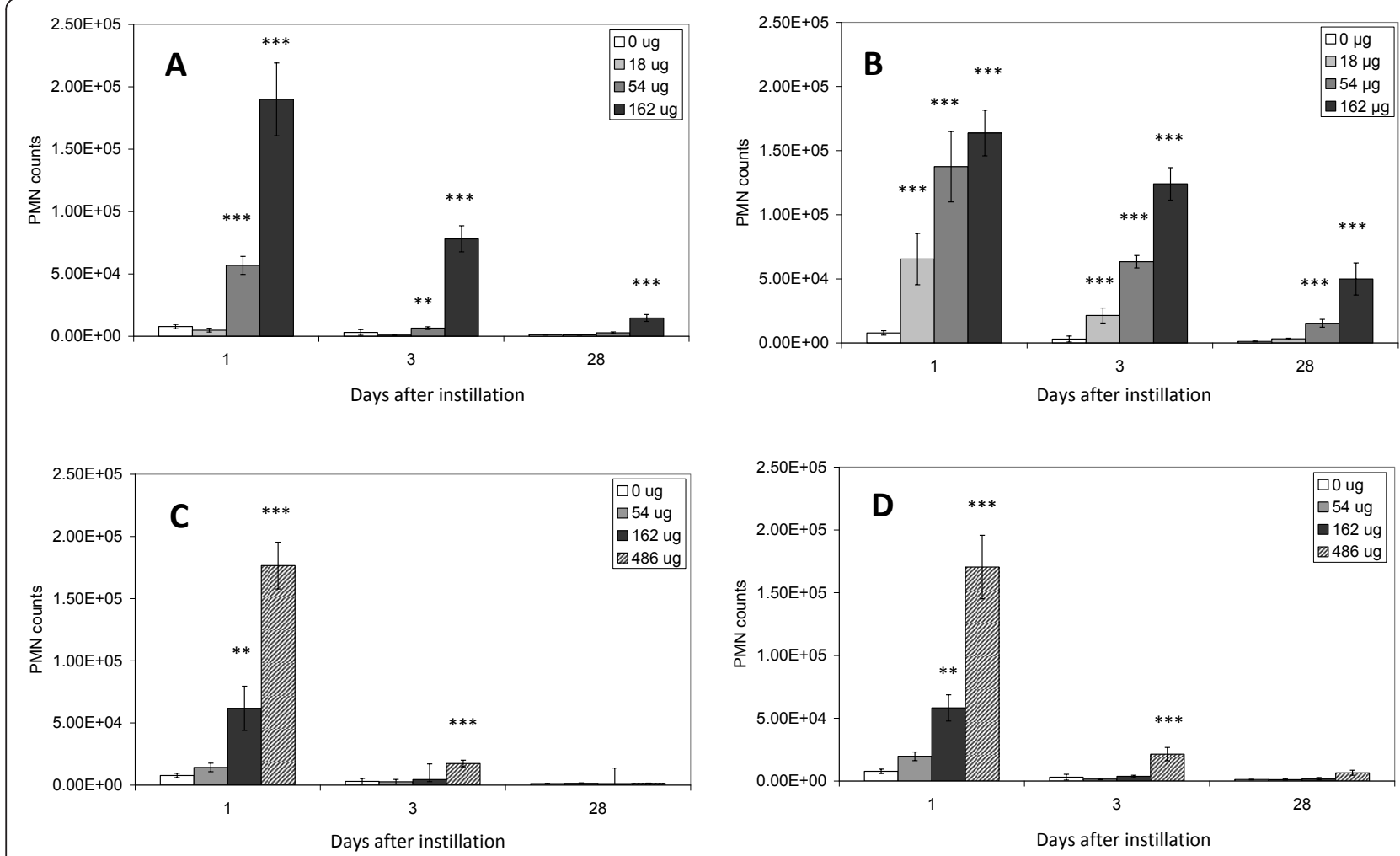

Figure 1 Neutrophil influx in the lungs. Neutrophil influx (PMN) in the lungs of mice exposed to $0,18,54$ or $162 \mu \mathrm{g}$ of $\mathrm{NanoTiO}_{2}(\mathrm{~A})$ or Printex 90 (B) or $0,54,162$ or $486 \mu \mathrm{g}$ of Indoor-R (C) or Indoor-NanoTiO ${ }_{2}$ (D). * ${ }^{* *}$, ***: Statistically significant compared to control mice at the $0.5,0.01$ and 0.001 level, respectively.

\section{Liver tissue}

Because only Printex 90 induced DNA strand breaks in BAL cells, initially we analysed the DNA damaging effect of the four materials only at the highest dose in liver $\left(162 \mu \mathrm{g}\right.$ for $\mathrm{NanoTiO}_{2}$ and Printex 90; $486 \mu \mathrm{g}$ for Indoor-Nano $\mathrm{TiO}_{2}$ and Indoor-R) at all time points. There was more DNA damage in hepatic tissue from mice exposed to Printex 90 and $\mathrm{NanoTiO}_{2}$ than in tissue from mice exposed to Indoor- $\mathrm{NanoTiO}_{2}$ and Indoor- $\mathrm{R}$ even though much higher doses were used for the paint dusts. Therefore the DNA damaging effects were examined at all doses and all times only after $\mathrm{NanoTiO}_{2}$ and Printex 90 exposures. Intratracheal instillation of $162 \mu \mathrm{g}$ of $\mathrm{NanoTiO}_{2}$ resulted in increased level of strand breaks in the liver 1 day after exposure, while this effect disappeared at the later time points (Figure 3. A). Printex 90 induced higher levels of DNA damage at all doses 1 and 28 days after intratracheal instillation, while there was no effect 3 days after intratracheal instillation (Figure 3.B) [19].

For the mice exposed to the two types of dusts, Indoor- $\mathrm{R}$ resulted in significant increased level of DNA strand breaks only on day 28 (Figure 3.C). However, we believe this was an artefact in the normalization due to a low plate control.

\section{Liver histology}

As compared to the controls histopathological lesions were observed in livers from mice exposed to $162 \mu \mathrm{g}$ of $\mathrm{NanoTiO}_{2}$ or Printex 90 at different time points (primarily at day 28) (Table 3 and Figure 4). All histopathological changes were slight in severity. No histopathological changes were recorded in livers from mice exposed to either $486 \mu \mathrm{g}$ of Indoor- $\mathrm{NanoTiO}_{2}$ or Indoor- $\mathrm{R}$ at any time point examined.

\section{Discussion}

In the present study, we investigated the dose-response relations of inflammation and DNA damage of one titanium dioxide nanomaterial (UV-Titan L181, code: Nano$\mathrm{TiO}_{2}$ ) and sanding dust from paints with (IndoorNanoTiO 2 ) and without $\mathrm{NanoTiO}_{2}$ (Indoor-R) 1, 3 and 28 days after a single intratracheal instillation in mice. Our results show that there was no additive effect of adding $\mathrm{NanoTiO}_{2}$ to the paint compared to the reference paint for any of the measured toxicological endpoints. Furthermore the results show that when evaluated on mass-basis, $\mathrm{NanoTiO}_{2}$ elicited greater pulmonary inflammation than the sanding dusts. $\mathrm{NanoTiO}_{2}$ caused DNA damage in liver tissue 1 day after intratracheal instillation, while no DNA damaging effects were observed in BAL cells at any of the 

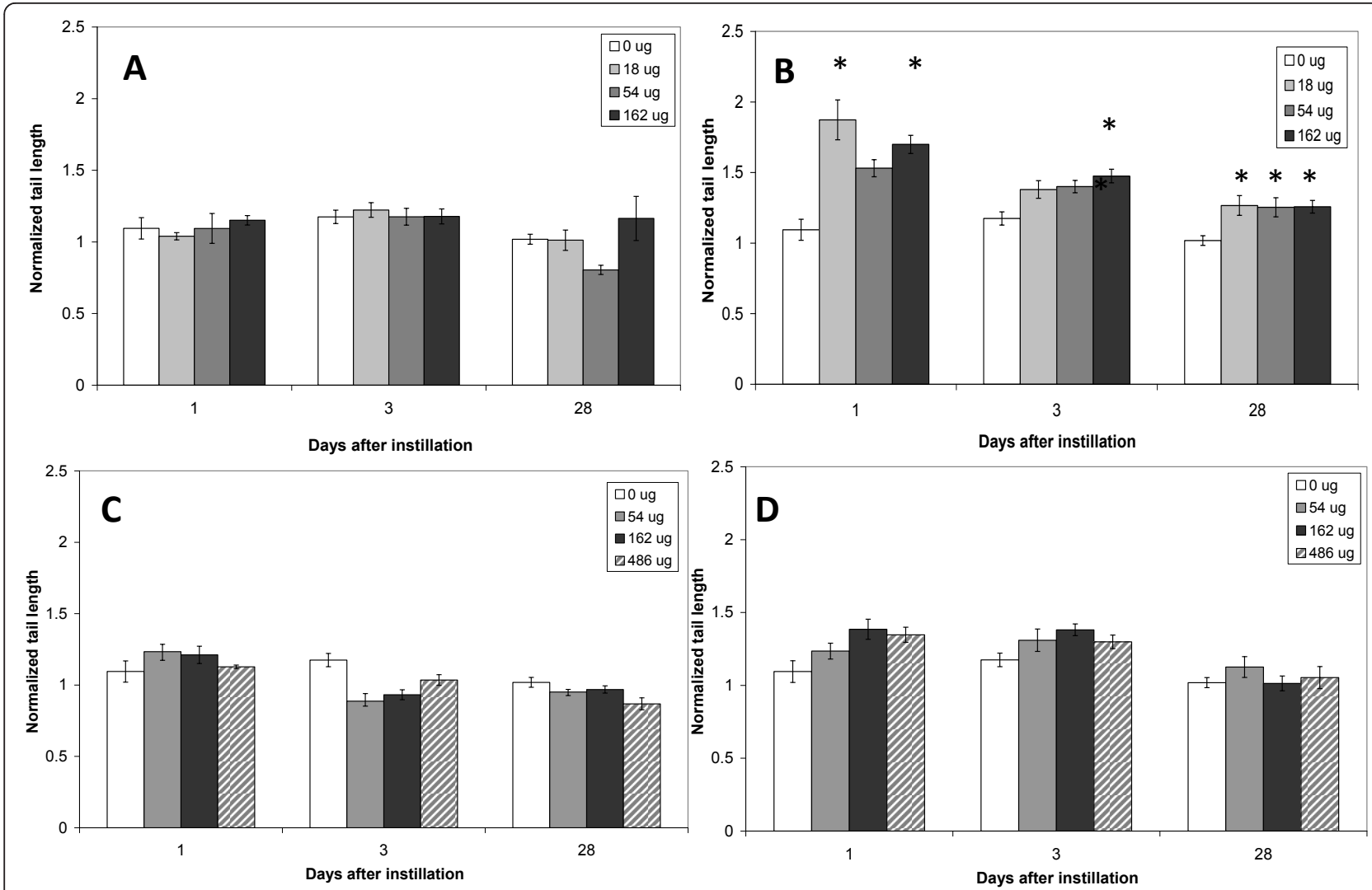

Figure 2 DNA strand breaks in BAL cells. DNA strand breaks in BAL cells obtained from mice exposed to $0,18,54$ or $162 \mu \mathrm{g}$ of $\mathrm{NanoTiO}_{2}(\mathrm{~A})$ or Printex 90 (B) or $0,54,162$ or $486 \mu \mathrm{g}$ of Indoor-R (C) or Indoor-NanoTiO 2 (D). The statistical analysis for Printex 90 has been described previously [19]. ${ }^{*}, * * * * *$ Statistically significant compared to control mice at the $0.5,0.01$ and 0.001 level, respectively.

measured time points. The sanding dusts caused neither DNA damage in the liver at the highest dose nor in the BAL cells at any dose except for the increased level of DNA damage in the liver from the Indoor-R exposed mice at day 28. However, we consider this finding likely to be a chance finding due to a low plate control used in the normalization procedure and due to the unusual kinetic of DNA damage (only DNA damage after 28 days). No histopathological lesions were detected in paint dust exposed mice, whereas modest histopathological changes were detected in livers of mice treated with the pure nanomaterials.

\section{Selection of test materials and study design}

The tested materials were chosen based on results from our two recent publications, in which we investigated the inflammatory and genotoxic effects in mice 1 day after a single dose $(54 \mu \mathrm{g})$ of 1$)$ a panel of nanoparticles with potential use in paints and lacquers [14] and 2) sanding dusts from a panel of paints with and without nanoparticles [12]. We found that despite that several of the nanoparticles were inflammogenic, the sanding dusts from nanoparticle containing paints did not result in an increased toxicological response compared to sanding dusts from reference paints. Based on these previous studies, we selected one $\mathrm{TiO}_{2}$ nanomaterial $\left(\mathrm{NanoTiO}_{2}\right)$ and sanding dusts from the corresponding paints with (Indoor- $\mathrm{NanoTiO}_{2}$ ) and without $\mathrm{NanoTiO}_{2}$ (Indoor-R) to be tested for dose-responses at different times because $\mathrm{NanoTiO}_{2}$ was inflammogenic and genotoxic [14]. The tested nanopaint contained $10 \% \mathrm{NanoTiO}_{2}$. To be able to compare the same amount of $\mathrm{NanoTiO}_{2}$ in paint we chose two different dose ranges for the pure $\mathrm{NanoTiO}_{2}(18,54,162 \mu \mathrm{g})$ and the sanding dusts (54, $162,486 \mu \mathrm{g})$. The $18 \mu \mathrm{g} \mathrm{NanoTiO}_{2}$ dose approximately corresponds to the $\mathrm{NanoTiO}_{2}$ content in a $162 \mu \mathrm{g}$ of sanding dust and similarly for the $54 \mu \mathrm{g}$ dose of Nano$\mathrm{TiO}_{2}$ and $486 \mu \mathrm{g}$ dose of sanding dust (Indoor-Nano$\mathrm{TiO}_{2}$ ). The carbon black type Printex 90 was included as a positive control because we have previously shown that Printex 90 is a potent ROS producer [15] that causes both DNA strand breaks and mutations [16].

\section{Dose considerations}

The $\mathrm{NanoTiO}_{2}$ doses $(18,54$ and $162 \mu \mathrm{g})$ equal $1.5,5$ and 15 working days at the Danish occupational 

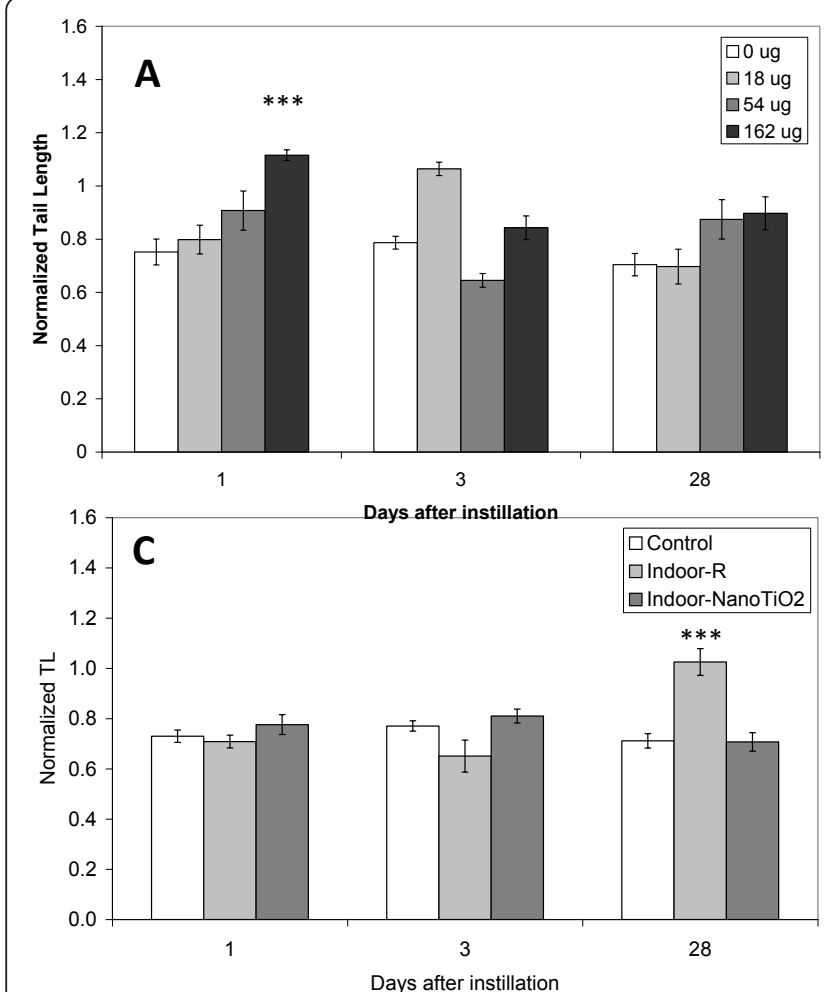

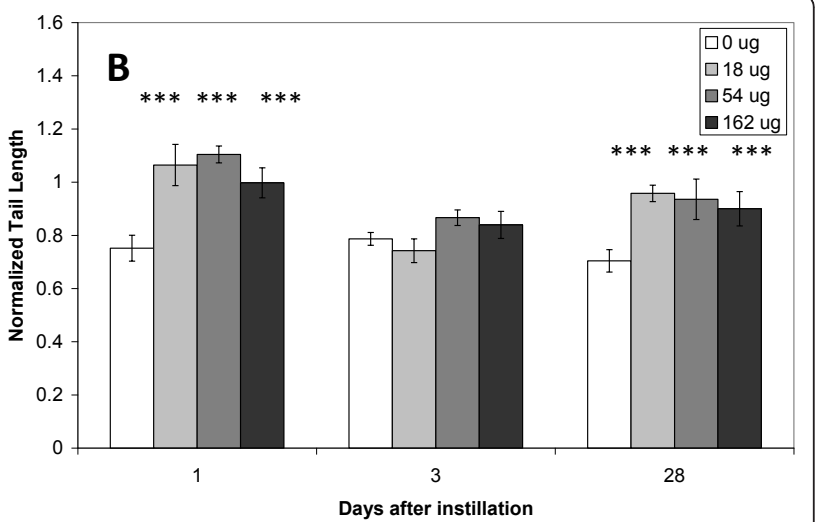

Figure 3 DNA strand breaks in hepatic tissue. DNA strand breaks in liver tissue from mice exposed to 0, 18, 54 or $162 \mu \mathrm{g}$ of $\mathrm{NanoTiO}_{2}(\mathrm{~A})$ or Printex 90 (B) or 0 or $486 \mu \mathrm{g}$ of Indoor-R or Indoor- $\mathrm{NanoTiO}_{2}$ (C). The statistical analysis for Printex 90 has been described previously [19]. The increased level of DNA strand breaks of Indoor-R is considered an artifact due to 1) a low plate control and the normalization procedure and 2) the unusual kinetic of DNA damage over time. ${ }^{*}, *^{* *}, *^{* *}$ : Statistically significant compared to control mice at the $0.5,0.01$ and 0.001 level, respectively.

exposure level for $\mathrm{TiO}_{2}\left(6.0 \mathrm{mg} \mathrm{Ti} / \mathrm{m}^{3} \sim 9.75 \mathrm{mg} \mathrm{TiO} /\right.$ $\mathrm{m}^{3}$ ) (assuming that $9 \%$ of the inhaled mass ends up in the pulmonary region [20], volume of inhaled air per hour $1.8 \mathrm{l} / \mathrm{h}$ [21] and 8 hour working days).

\section{Toxicity of NanoTiO2 when bound in a paint matrix}

Our previous single dose study of a range of different paint dusts in mice 1 day after intratracheal instillation showed that the majority of nanoparticles seem to stay in the paint matrix after sanding [12]. This is also the general view that exposure to nanosized titanium dioxide occurring during use of products is insignificant when the titanium dioxide is bound to other materials, such as in paints [22]. In the present study, we compared the dose-response relations at several time points of $\mathrm{NanoTiO}_{2}$ as part of a paint matrix with the effects of pure $\mathrm{NanoTiO}_{2}$. By choosing the different dose ranges for $\mathrm{NanoTiO}_{2}$ and sanding dusts, the study was designed to investigate whether it was possible to detect an additive effect or synergetic effect of the $\mathrm{NanoTiO}_{2}$ in the Indoor- $\mathrm{NanoTiO}_{2}$ compared to the Indoor- $\mathrm{R}$. However, no increase in any of the toxicological endpoints was detected for the Indoor- $\mathrm{NanoTiO}_{2}$ compared to the Indoor-R. SEM analysis of the Indoor-NanoTiO suspension used for instillation indicated that most of the $\mathrm{NanoTiO}_{2}$ apparently was retained in the paint matrix [12]. Immediately, the results suggest that the inflammogenic effects of $\mathrm{NanoTiO}_{2}$ are masked when incorporated into a matrix and this may explain why we observed the same inflammatory response for both paints. If an additive effect was expected (e.g, all included $\mathrm{NanoTiO}_{2}$ was bio accessible), we would have observed a $20 \%$ increase in the number of neutrophils at day 1.

The instilled dose of Indoor-NanoTiO 2 can be viewed as the combination of the middle dose of $\mathrm{NanoTiO}_{2}$ (54 $\mu \mathrm{g})$ and the highest dose of Indoor- $\mathrm{R}(486 \mu \mathrm{g})$. We observed induction of liver DNA damage only at the highest dose of $\mathrm{NanoTiO}_{2}$ and not at the high dose of Indoor- $\mathrm{NanoTiO}_{2}$. The induction of liver DNA damage by Indoor-R we think was a chance finding. Thus, taking these results into account, we did not expect that exposure to Indoor-Nano $\mathrm{TiO}_{2}$ at the chosen dose would lead to genotoxicity and the results confirm this. Because similar toxicological responses for the measured endpoints were observed for the nanoparticle containing 
Table 3 Type and incidence of histopathological lesions.

\begin{tabular}{|c|c|c|c|c|c|}
\hline Type of lesion/post-treatment day & Control & Nano $\mathrm{TiO}_{2}$ & Indoor-Nano $\mathrm{TiO}_{2}$ & Indoor-R & Printex 90 \\
\hline \multicolumn{6}{|l|}{ Foci (small) of inflammatory cells } \\
\hline Day 1 & $0 / 3^{a}$ & $1 / 4$ & $0 / 6$ & $0 / 6$ & $0 / 4$ \\
\hline Day 3 & $0 / 3$ & $0 / 4$ & $0 / 5$ & $0 / 6$ & $0 / 4$ \\
\hline Day 28 & $0 / 5$ & $1 / 5$ & $0 / 5$ & $0 / 5$ & $0 / 6$ \\
\hline \multicolumn{6}{|l|}{ Polymorphonuclear cell foci } \\
\hline Day 1 & $0 / 3$ & $0 / 4$ & $0 / 6$ & $0 / 6$ & $1 / 4$ \\
\hline Day 3 & $0 / 3$ & $0 / 4$ & $0 / 5$ & $0 / 6$ & $2 / 4$ \\
\hline Day 28 & $0 / 5$ & $0 / 5$ & $0 / 5$ & $0 / 5$ & $2 / 6$ \\
\hline \multicolumn{6}{|c|}{ Hyperplasia of connective tissue perivascular } \\
\hline Day 1 & $0 / 3$ & $1 / 4$ & $0 / 6$ & $0 / 6$ & $0 / 4$ \\
\hline Day 3 & $0 / 3$ & $1 / 4$ & $0 / 5$ & $0 / 6$ & $0 / 4$ \\
\hline Day 28 & $0 / 5$ & $1 / 5$ & $0 / 5$ & $0 / 5$ & $0 / 6$ \\
\hline \multicolumn{6}{|c|}{ Hyperplasia of connective tissue near bile ductules or venules } \\
\hline Day 1 & $0 / 3$ & $0 / 4$ & $0 / 6$ & $0 / 5$ & $0 / 4$ \\
\hline Day 3 & $0 / 3$ & $0 / 4$ & $0 / 5$ & $0 / 6$ & $0 / 4$ \\
\hline Day 28 & $0 / 5$ & $0 / 5$ & $0 / 5$ & $0 / 5$ & $3 / 6$ \\
\hline \multicolumn{6}{|l|}{ Necrosis in centrilobular area } \\
\hline Day 1 & $0 / 3$ & $0 / 4$ & $0 / 6$ & $0 / 6$ & $0 / 4$ \\
\hline Day 3 & $0 / 3$ & $0 / 4$ & $0 / 5$ & $0 / 6$ & $0 / 4$ \\
\hline Day 28 & $0 / 5$ & $3 / 5$ & $0 / 5$ & $0 / 5$ & $0 / 6$ \\
\hline \multicolumn{6}{|l|}{ Microfoci of necrosis in centrilobular area } \\
\hline Day 1 & $0 / 3$ & $0 / 4$ & $0 / 6$ & $0 / 6$ & $0 / 4$ \\
\hline Day 3 & $0 / 3$ & $0 / 4$ & $0 / 5$ & $0 / 6$ & $0 / 4$ \\
\hline Day 28 & $0 / 5$ & $0 / 5$ & $0 / 5$ & $0 / 5$ & $1 / 6$ \\
\hline \multicolumn{6}{|c|}{ Eosinophilic necrosis in single hepatocytes } \\
\hline Day 1 & $0 / 3$ & $0 / 4$ & $0 / 6$ & $0 / 6$ & $0 / 4$ \\
\hline Day 3 & $0 / 3$ & $0 / 4$ & $0 / 5$ & $0 / 6$ & $0 / 4$ \\
\hline Day 28 & $0 / 5$ & $0 / 5$ & $0 / 5$ & $0 / 5$ & $1 / 6$ \\
\hline \multicolumn{6}{|l|}{ Hepatocytes with pycnotic nuclei } \\
\hline Day 1 & $0 / 3$ & $0 / 4$ & $0 / 6$ & $0 / 6$ & $1 / 4$ \\
\hline Day 3 & $0 / 3$ & $0 / 4$ & $0 / 5$ & $0 / 6$ & $1 / 4$ \\
\hline Day 28 & $0 / 5$ & $0 / 5$ & $0 / 5$ & $0 / 5$ & $1 / 6$ \\
\hline \multicolumn{6}{|l|}{ Parenchymal degeneration } \\
\hline Day 1 & $0 / 3$ & $0 / 4$ & $0 / 6$ & $0 / 6$ & $0 / 4$ \\
\hline Day 3 & $0 / 3$ & $0 / 4$ & $0 / 5$ & $0 / 6$ & $0 / 4$ \\
\hline Day 28 & $0 / 5$ & $2 / 5$ & $0 / 5$ & $0 / 5$ & $3 / 6$ \\
\hline \multicolumn{6}{|l|}{ Binucleate hepatocytes } \\
\hline Day 1 & $0 / 3$ & $1 / 4$ & $0 / 6$ & $0 / 5$ & $0 / 4$ \\
\hline Day 3 & $0 / 3$ & $0 / 4$ & $0 / 5$ & $0 / 6$ & $0 / 4$ \\
\hline Day 28 & $0 / 5$ & $0 / 5$ & $0 / 5$ & $0 / 5$ & $2 / 6$ \\
\hline \multicolumn{6}{|c|}{ Oedema of endothelial cells of portal venules } \\
\hline Day 1 & $0 / 3$ & $0 / 4$ & $0 / 5$ & $0 / 6$ & $0 / 4$ \\
\hline Day 3 & $0 / 3$ & $0 / 4$ & $0 / 5$ & $0 / 6$ & $0 / 4$ \\
\hline Day 28 & $0 / 5$ & $0 / 5$ & $0 / 6$ & $0 / 5$ & $2 / 6$ \\
\hline \multicolumn{6}{|l|}{ Increased number of Kupffer cells ${ }^{b}$} \\
\hline Day 1 & $0 / 3$ & $2 / 4$ & $0 / 6$ & $0 / 6$ & $1 / 4$ \\
\hline Day 3 & $0 / 3$ & $2 / 4$ & $0 / 5$ & $0 / 6$ & $1 / 4$ \\
\hline Day 28 & $0 / 5$ & $2 / 5$ & $0 / 5$ & $0 / 5$ & $2 / 6$ \\
\hline
\end{tabular}

Type and incidence of histopathological lesions in the control mice and mice exposed to $162 \mu \mathrm{g}$ of $\mathrm{NanoTiO}_{2}, 486 \mu \mathrm{g}$ Indoor-NanoTiO ${ }_{2}, 486 \mu \mathrm{g}$ Indoor-R, or 162 $\mu \mathrm{g}$ of Printex $90 .{ }^{\mathrm{a}}$ : Incidence of a lesion expressed as a number of livers with the lesion of a total number of examined livers. ${ }^{\mathrm{b}}$ : Qualitative evaluation only. 

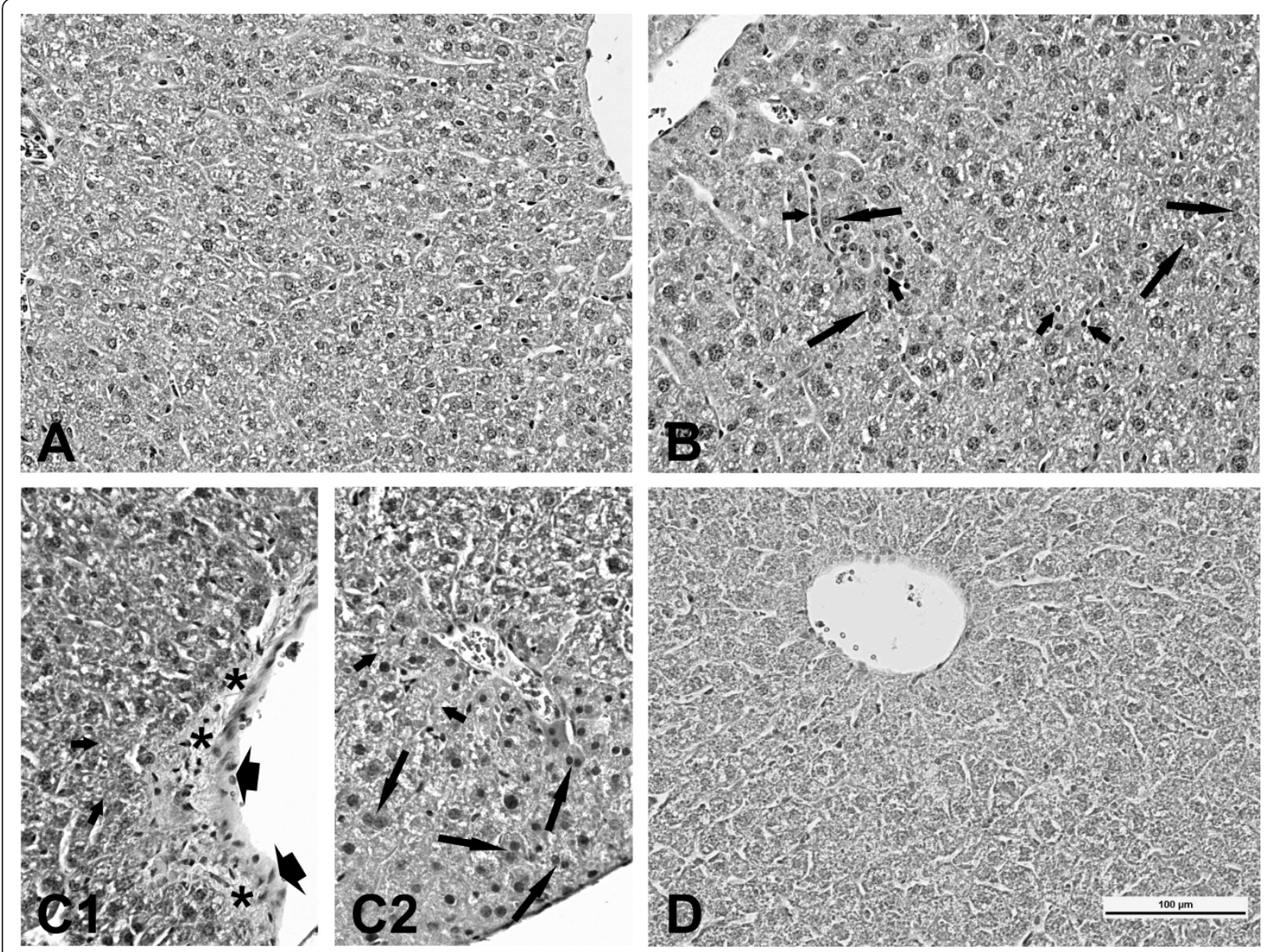

Figure 4 Liver histology. Microscopic pattern of the liver mice: A (vehicle exposed control animals) - normal structure; B (mice exposed to $\mathrm{NanoTiO}_{2}-24 \mathrm{~h}$ after exposure) - infiltration of inflammatory cells (short arrows), binucleate hepatocytes (long arrows); $\mathrm{C}$ (mice exposed to Printex 90 - 28 days after exposure) - microfoci of necrosis (short arrows), C1 - edematous of endothelial cells (head of arrows), hyperplasia of connective tissue (asterisks), C2 - binucleate hepatocytes (long arrows); D (dust from Indoor-NanoTiO 2 - 3 days after exposure) - normal structure: staining $H E$, magnification as scale on the figure $D$.

paint compared to the conventional paint, our data support our previous findings showing that nanomaterials bound in a paint dust do not contribute to the observed toxicity [12]. Therefore, our results support a very recent publication by Wohlleben et al. investigating the inflammatory and genotoxic response of nanomaterials and sanding dusts from cement and plastic composites with and without nanomaterial after intratracheal instillation in rats [6]. In that study, similar to our study no additional toxicity was observed for the nanomaterial containing dusts compared to dusts from reference products.

\section{Pulmonary inflammation}

For all the tested materials the greatest number of neutrophils was observed 1 day after exposure. Mice exposed to the highest dose of $\mathrm{NanoTiO}_{2}(162 \mu \mathrm{g})$ still had increased numbers of neutrophils 28 days after exposure. This is in line with our previous publication showing increased inflammation in mice 4 weeks after end of exposure to the same $\mathrm{NanoTiO}_{2}$ by inhalation to $42 \mathrm{mg} / \mathrm{m}^{3}$ aerolized powder for $1 \mathrm{~h} /$ day on 11 consecutive days [20]. In that study, $21 \%$ of the deposited $\mathrm{NanoTiO}_{2}$ could be detected in lung tissue 28 days after last exposure. The neutrophil influx in mice exposed to the two different sanding dusts were similar to each other and of much smaller scale than the inflammation in mice exposed to nanomaterials when comparing the mass dose.

There is much evidence that the inflammatory response induced by low-toxicity low-solubility particles correlates well with the instilled surface area of the particles [14,23-26]. We found that the specific surface area of $\mathrm{NanoTiO}_{2}$ and Printex 90 correlated strongly with the influx of neutrophils (Figure 5). The results show 


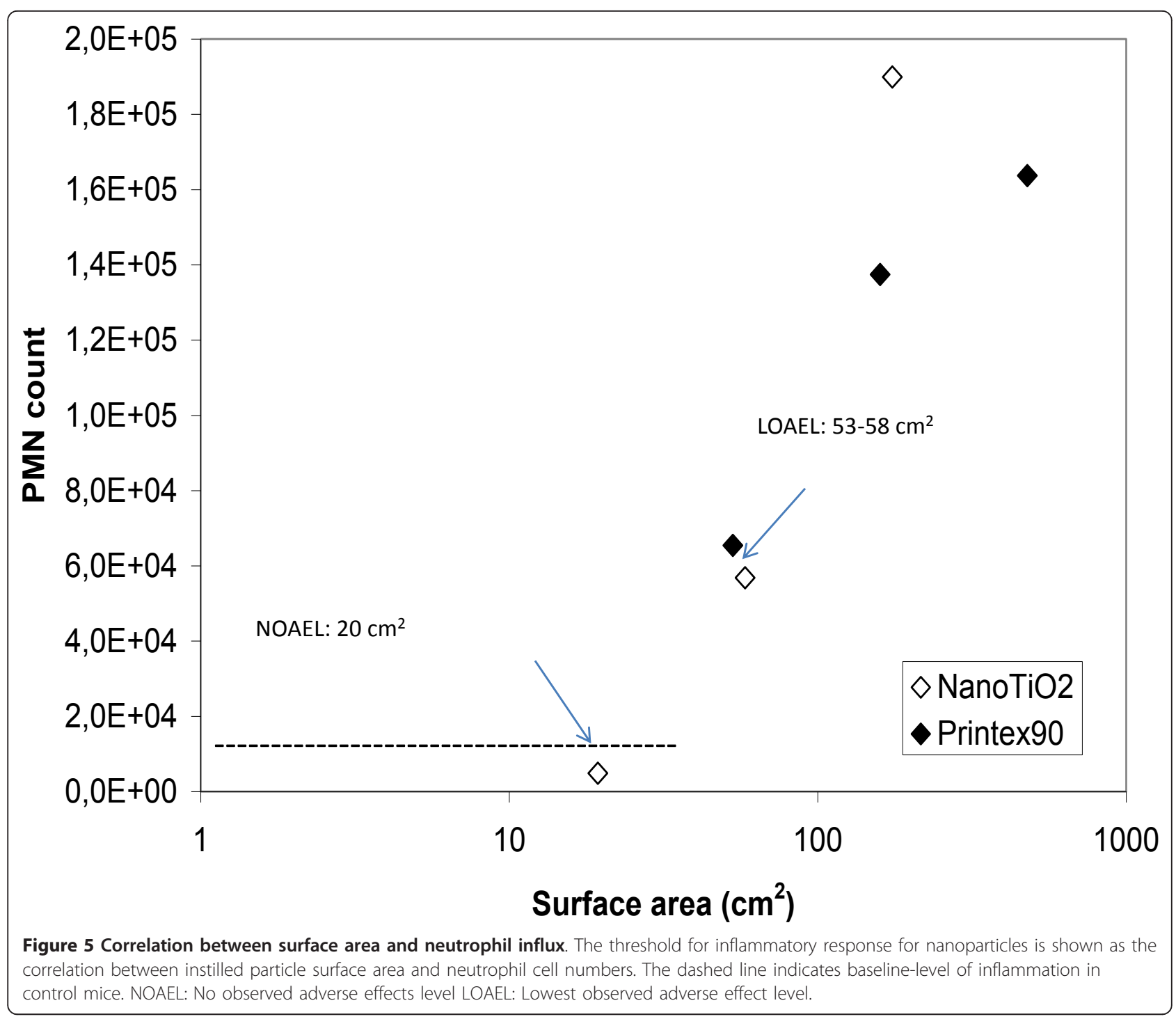

that the NOEL is $19 \mathrm{~cm}^{2}$ and the LOEL is 53 and 58 $\mathrm{cm}^{2}$ (Printex 90 and $\mathrm{NanoTiO}_{2}$, respectively). Our results are in line with a previous study by Stöger and colleagues demonstrating the existence of a threshold for the particle surface area at an instilled dose of approximately $20 \mathrm{~cm}^{2}$, below which no inflammatory responses could be detected in mice 1 day after intratracheal instillation [27]. In the present study, the effects were reversible over time. The neutrophilic response declined over time from day 1 to 3 and to 28 days after intratracheal instillation. BET analysis was not possible for the paint dust particles due to insufficient amounts of materials. However, estimations from the total airborne particle surface areas and volumes in Koponen et al. [7], suggest that the volume specific surface areas of the sanding dust particles were in the order of 2.8 to 3.5 $\mathrm{m}^{2} / \mathrm{cm}^{3}$. The specific surface area of $\mathrm{NanoTiO}_{2}$ and
Printex 90 were 107.7 and $295 \mathrm{~m}^{2} / \mathrm{g}$, respectively. Hence, assuming a density of $1 \mathrm{~g} / \mathrm{ml}$, the instilled paint surface area will only be on the order of 1 to $3 \%$ of the specific surface area for the same dose of the pure nanomaterials. This suggests that other factors such as particle chemistry are also important for the toxicity.

\section{Pulmonary fibrosis}

Some nanomaterials have been shown to induce fibrosis as e.g. CNTs [17]. The pulmonary Tgf- $\beta$ mRNA expression level was assessed as a marker for a profibrotic response. The level of TGF- $\beta$ in BAL fluid was increased in mice exposed to CNTs after exposure by apiration [28] and by intratracheal instillation [29]. However, in the present study the Tgf- $\beta$ mRNA expression levels were not affected by exposure to any of the tested materials (all doses at all time points) compared to control 
mice. It is possible that we by measuring $T g f-\beta$ mRNA expression levels at 1,3 and 28 days after intratracheal instillation missed the optimal time frame for assessing TGF- $\beta$. In both the above mentioned studies a maximum for the TGF- $\beta$ level in BAL fluid was found 7 days after exposure. However, another explanation for the differences could be that the tested materials in the present study do not have the same fibrous nature as CNTs. Our results are in line with a recent study of markers of inflammation and fibrosis in mice where no increase in TGF- $\beta 1$ level in BAL fluid was found 2,7 , 14 and 21 days after intratracheal instillation of $10 \mu \mathrm{g}$ Printex 90 [30]. It should be noted that fibrosis is a very complex pathway. We chose to evaluate $T g f-\beta$ mRNA expression as a marker of fibrosis because this marker has been used previously with success within the area of nanotoxicology [28]. However, a panel of markers for tissue fibrosis exists [31] and it might be that other markers of fibrosis would have been informative as well.

\section{DNA damage in BAL cells}

In BAL cells, except for the reference particle Printex 90 [19] none of the tested products induced DNA damage by the comet assay. So the data suggest that the products do not cause DNA damage at the time of analysis, when evaluated by the Comet assay. The reference particle Printex 90 caused DNA damage in BAL cells 1 day after intratracheal instillation at all tested doses. We have previously shown that exposure to Printex 90 resulted in DNA damage 3 hours after pulmonary exposure in ApoE-/- mice [26]. DNA strand breaks last only for a short-term, probably because the DNA damage is rapidly repaired by DNA repair enzymes [32].

\section{Hepatic effects}

In the liver, $\mathrm{NanoTiO}_{2}$ induced DNA damage 1 day after intratracheal instillation at the highest dose tested, while no effect was seen in sanding dust exposed mice. The reference particle Printex 90 caused a biphasic response for the DNA damage [19].

Exposure of mice to the sanding dust from paints with and without $\mathrm{NanoTiO}_{2}$ was not associated with any hepatic histopathological changes compared to the vehicle controls. In contrast, exposure to $\mathrm{NanoTiO}_{2}$ and to Printex 90 was associated with modest histopathological changes in the liver primarily at day 28 (Table 3, Figure 4).

An increased number of binucleate hepatocyte can be indicative of a regenerative activity in the tissue exposed to a toxic agent [33]. Changes such as inflammatory cell foci, polymorphonuclear cell foci, or microfoci of necrosis are known to occur also under physiological conditions in untreated animals [34] and binucleate hepatocytes are often noted in the aged mice [34]. On the other hand, the animals used in the present study were 12 weeks at the latest time point and no changes were observed in the control mice. The hepatic effects in terms of DNA damage and modest histological changes seen in the present study can hypothetically be caused both by systemic inflammation and by direct effects of translocated particles. That we detected the largest effects with the smallest particles $\left(\mathrm{NanoTiO}_{2}\right.$ and Printex 90) support an interpretation that the observed hepatic effects may indeed be caused by nanoparticle exposure because: 1) $\mathrm{NanoTiO}_{2} /$ Printex 90 caused more persistent inflammation over time than the sanding dusts, and 2) the translocation of $\mathrm{NanoTiO}_{2} /$ Printex 90 would be expected to be larger than the sanding dusts due to their smaller size. Hepatic DNA damage following Printex 90 exposure was reported in our recent publication showing DNA strand breaks in time-mated mice exposed by inhalation to $42 \mathrm{mg} / \mathrm{m}^{3}$ Printex 90 for $1 \mathrm{~h} /$ day on gestation days (GD) 8-18 mice 5 and 24 days after inhalation exposure, while no effect was found after intratracheal instillation of corresponding pulmonary dose at similar time-points [35]. Histopathological changes such as cytoplasmic vacuolisation and hepatic focal necrosis or minimal to moderate bile duct hyperplasia, single cell necrosis (characterized by increased cellular eosinophilia and shrunken condensed nuclei), and moderate multifocal necrosis were reported in some of the rats exposed by inhalation to either $19 \mathrm{~nm}$ silver nanoparticles (6 h/day, 5 days/week, for 13 weeks) [36] or to silver nanoparticles sized 2-65 nm (6 h/day, 5 days/week, for 4 weeks) [37].

\section{Conclusions}

$\mathrm{NanoTiO}_{2}$ did not induce DNA damage in lung lining cells despite being highly inflammogenic. In contrast, NanoTiO ${ }_{2}$ induced hepatic DNA damage at the highest tested dose. Sanding dusts from both paints resulted in increased pulmonary inflammation while no DNA damage was observed in BAL cells or liver tissue. The level of pulmonary inflammation in mice exposed to sanding dust was not affected by the addition of nanoparticles to paint.

\section{Methods}

\section{Animals}

Female C57BL/6 mice 5-7 weeks old were obtained from Taconic (Ry, Denmark). The mice were allowed to acclimatize for 1-3 weeks before the experiment. All mice were given food (Altromin no. 1324, Christian Petersen, Denmark) and water ad libitum during the whole experiment. The mice were group housed in polypropylene cages with sawdust bedding and enrichment at controlled temperature $21 \pm 1^{\circ} \mathrm{C}$ and humidity $50 \pm$ $10 \%$ with a 12-h light:12-h dark cycle. Female mice were 
studied at 8 weeks of age. The experiments were approved by the Danish "Animal Experiments Inspectorate" and carried out following their guidelines for ethical conduct and care when using animals in research.

\section{Particles and sanding dusts Products}

The Danish paint and lacquer industry provided an indoor acrylic paint product with $10 \%$ content of Nano$\mathrm{TiO}_{2}$ (referred as Indoor-NanoTiO${ }_{2}$ ) and a corresponding product without nanoparticles (referred to as Indoor R) (Table 1). The tested pure nanomaterials comprised of a nanosized $\mathrm{TiO}_{2}$ material (UV-Titan L181, code: $\mathrm{NanoTiO}_{2}$ ), and carbon black (Printex 90), which was included as an internal reference particle. Printex 90 was a gift from Degüssa (Germany). As reported previously, the specific surface areas of the particles were $295 \mathrm{~m}^{2} / \mathrm{g}$ for Printex 90 [38] and $107.7 \mathrm{~m}^{2} / \mathrm{g}$ for NanoTiO2 [14]. The nanoparticles and the paints are described in detail in [12] and [14].

\section{Generation of dusts}

Dusts were generated by sanding of boards painted with the two selected paints paints as described previously [7]. Briefly, dust samples were collected by an electrostatic precipitor. The device was modified from a commercial air cleaner and is described in details in [18]. Paint dust was deposited on the silver coated plates. After sampling the plate holder system was covered with Aluminum-foil and carefully transported to the laboratory where dust was removed from the plates using a silicon scraper. The samples were stored in the freezer until toxicological testing.

\section{Preparation of exposure stock}

Particles were suspended by sonication in $0.9 \% \mathrm{NaCl}$ MilliQ water containing $10 \% \mathrm{v} / \mathrm{v}$ acellular BAL collected from $\mathrm{C} 57 \mathrm{BL} / 6$ mice. The BAL fluid was prepared by flushing unexposed mice twice to $0.6 \mathrm{ml} 0.9 \% \mathrm{NaCl}$ yielding approximately $1 \mathrm{ml}$ of BAL fluid. Acellular BAL was prepared by centrifugation of BAL fluid at $400 \mathrm{~g}$ $\left(10 \mathrm{~min}, 4^{\circ} \mathrm{C}\right)$. The particles $(4.05 \mathrm{mg} / \mathrm{ml})$ and dust suspensions $(12.15 \mathrm{mg} / \mathrm{ml})$ were sonicated using a Branson Sonifier S-450D (Branson Ultrasonics Corp., Danbury, CT, USA) equipped with a disruptor horn (Model number: 101-147-037). Total sonication time was $16 \mathrm{~min}$, with alternating $10 \mathrm{~s}$ pulses and $10 \mathrm{~s}$ pauses at amplitude of $10 \%$ (8 min sonication total). During the sonication procedure the samples were continuously cooled on ice. These suspensions were used for the high dose (486 $\mu \mathrm{g}$ (dust) and $162 \mu \mathrm{g}\left(\mathrm{NanoTiO}_{2} /\right.$ Printex 90)) and diluted 1:3 for the medium dose and diluted further 1:3 for the low dose. Between the dilutions the suspensions were pipetted. Vehicle control solutions were prepared containing $90 \% 0.9 \% \mathrm{NaCl}$ MilliQ water and $10 \%$ acellular BAL fluid.

\section{Characterization of exposure}

Characterization of the materials in instillation vehicle have been published previously [12,14]. Briefly, the average size of the materials in instillation vehicle were determined by Dynamic Light Scattering (DLS) and the shapes of the materials and the extent of agglomeration/ aggregation in instillation vehicle were characterized by transmission electron microscopy (TEM) and scanning electron microscopy (SEM). TEM pictures of the Nano$\mathrm{TiO}_{2}$ suspension used for instillation showed that the individual nanoparticles mainly occurred in partially open to dense aggregates of ca. $100 \mathrm{~nm}$ size or larger and the size-distribution plot by DLS indicated a multimodal size-distribution with two modes in the $\mu \mathrm{m}$-range (peaks at 5.5 and $2.3 \mu \mathrm{m}$ ) and one in the sub- $\mu \mathrm{m}$ range $(825 \mathrm{~nm})$ [14]. SEM analysis of the Indoor-NanoTiO and Indoor-R suspensions used for instillation suggests that most of the nanoparticles were still fully or partially encapsulated in the paint matrix after sanding. However, a considerable amount of the pigment particles were generally liberated from the matrix. Due to the size of the coarse dust fraction and sedimentation, DLS analysis was not reliable for the un-filtered dispersions of dusts [12].

\section{Measurement of endotoxin}

An amount of $4.05 \mathrm{mg} / \mathrm{ml}$ of each type of nanoparticle and dust was suspended in pyrogen free water with $0.05 \%$ Tween 20 by orbital shaking (300 rpm) at room temperature. The particles were suspended by sonification as described above. The suspensions were centrifuged $(20.000 \mathrm{rpm})$ for $6 \mathrm{~min}$, and the supernatant was used for endotoxin assay. The endotoxin contents were analysed in duplicate using the kinetic Limulus Amebocyte Lysate test (Kinetic-QCL endotoxin kit, Lonza, Walkersville, MD, USA). A standard curve (ranging from 0.05 to $50 \mathrm{EU} / \mathrm{ml}$ ) obtained from an Escherichia coli O55:B5 reference endotoxin was used to determine the concentrations in terms of endotoxin units (EU) $(15.0 \mathrm{EU}=1 \mathrm{ng})$. In addition inhibition/enhancement controls were prepared by spiking supernatants from sample Indoor-NanoTiO $\mathrm{Ti}_{2}$, Indoor- $\mathrm{R}, \mathrm{TiO}_{2}$ and Printex 90 with $10 \mu \mathrm{l}$ of a $0.5 \mathrm{EU} / \mathrm{ml}$ solution of endotoxin. As a control of the method $\mathrm{NanoTiO}_{2}$ and Printex 90 were tested twice (on two plates) and less than $16 \%$ variance was found.

\section{Exposure of mice}

The mice were treated with a single intratracheal instillation with 18, 54 and $162 \mu \mathrm{g}$ for the nanoparticles and 
54, 162 and 486 for the paint dusts. To eliminate day to day variation, 3-4 materials including vehicle controls were instilled on each exposure day and each material dose was instilled on three separate days. Before the intratracheal instillation, the mice were anesthetized using Hypnorm $^{\circledR}$ (fentanyl citrate $0.315 \mathrm{mg} / \mathrm{ml}$ and fluanisone $10 \mathrm{mg} / \mathrm{ml}$ from Janssen Pharma) and Dormicum $^{\circledR}$ (Midazolam $5 \mathrm{mg} / \mathrm{mL}$ from Roche). Both were mixed with equal volume sterile water. A volume of 0.2 $\mathrm{ml}$ was injected subcutaneously into the loose skin over the neck of each mouse. The sedated mice were kept on $37^{\circ} \mathrm{C}$ heating plates. During instillation the mice were placed on their backs on a 40 degree slope. A one diode cold light source was placed touching the larynx. The tongue was pressed towards the lower jaw by a small spatula. The trachea was intubated using a 24 gauge BD Insyte catheter (Ref: 381212, Becton Dickinson, Denmark) with a shortened needle. The correct location of each intubation was tested by a small but highly sensitive pressure transducer (pneutachymeter), developed by our laboratory in collaboration with John Frederiksen (FFE/P, Copenhagen, Denmark). A $40 \mu$ l suspension was instilled followed by $150 \mu \mathrm{l}$ air with a $250 \mu \mathrm{l} \mathrm{SGE}$ glass syringe (250F-LT-GT, MicroLab, Aarhus, Denmark). Control animals were instilled with vehicle $(0.9 \% \mathrm{NaCl}$ with $10 \% \mathrm{BAL})$. After the intubation catheter was removed, the mousebreathing was observed in order to assure that the delivered material did not block the airways. The mice were placed on to the $37^{\circ} \mathrm{C}$ heating plate until they recovered from anaesthesia.

\section{Preparation of tissue and cells from the mice}

One, 3 or 28 days after intratracheal instillation, the mice were anaesthetised with Hypnorm/Dormicum as described above. Immediately after withdrawing the heart blood, a bronchoalveolar lavage (BAL) was performed four times with $0.8 \mathrm{~mL}$ of $0.9 \%$ sterile saline through the trachea. The BAL was immediately put on ice until BAL fluid and BAL cells were separated by centrifugation at $4{ }^{\circ} \mathrm{C}$ and $400 \mathrm{~g}$ for $10 \mathrm{~min}$. The BAL cells were resuspended in $100 \mu \mathrm{L}$ medium (HAMF12 with $10 \%$ fetal bovine serum). Part of the suspension (40 $\mu \mathrm{L}$ ) was mixed with $160 \mu \mathrm{L}$ medium containing $10 \%$ DMSO and stored at $-80^{\circ} \mathrm{C}$ for later analysis in the comet assay. For differential count, cells from $50 \mu \mathrm{L}$ suspension were collected on microscope slides by centrifugation at $10,000 \mathrm{rpm}$ for $4 \mathrm{~min}$ in a Cytofuge 2 (StatSpin, Bie and Berntsen, Rødovre, Denmark). The slides were fixed with $96 \%$ ethanol and stained with May-Grünwald-Giemsa stain. The cellular composition of BAL cells was determined on 200 cells. The total number of cells was determined by using the NucleoCounter (Chemometec, Allerød, Denmark) live/dead assay according to the manufacturer's instructions. The lungs and a piece of liver tissue were snap frozen in cryotubes (NUNC) in liquid $\mathrm{N}_{2}$ and stored at $-80^{\circ} \mathrm{C}$. From vehicle controls and high dose groups exposed to each of the test materials (3-6 per group) another piece of liver tissue from the left lobe was kept in formaldehyde (4\%) until liver histology was performed.

\section{Preparation of RNA and cDNA from lung tissue}

RNA was prepared using the NucleoSpin 96 RNA kit (Macherey-Nagel). RNA from the entire left lung of each mouse was prepared by lysing the tissue in $2 \mathrm{ml}$ RLT buffer, while vigorously disrupting the sample with a Tissuelyser (Qiagen, Denmark) with a $5 \mathrm{~mm}$ stainless steel bead for $2 \times 60$ seconds and run through a QIAshredder (Qiagen, USA). The rest of the purification was performed as described by the manufacturer. cDNA was prepared using TaqMan reverse transcription reagents (Applied Biosystems, USA) as described by manufacturer.

\section{Real-time RT-PCR}

The Tgf- $\beta 1$ gene expression was determined using realtime RT-PCR with 18S RNA as reference gene (Kit nr. Mm03024053_m1 from Applied Biosystems). RT-PCR was performed using Universal Mastermix (Applied Biosystems, Nærum, Denmark). PCR was performed on an ABI PRISM ${ }^{\circledR} 7500$ sequence detector (PE Biosystems, Foster City, CA, USA) as described previously [39]. 18S (4310893E, Applied Biosystems, Nærum, Denmark) was used as the reference gene. Expression for each gene was quantified in separate wells. Samples were quantified in triplicates; standard deviation was below $20 \%$. Run to run variation was controlled by quantifying the mRNA levels for the same control sample. The standard deviation in separate runs was lower than $25 \%$. No template and -RT controls were included in all runs.

\section{Comet assay}

The level of DNA strand breaks in frozen BAL and liver tissue was determined by the alkaline comet assay as described in $[40,41]$ based on a protocol by [42]. The strand breaks measured by the assay represent a mixture of direct strand breaks, alkaline labile sites and transient breaks in the DNA due to repair processes [43]. The samples were analyzed using a high throughput allowing 48 samples per GelBondfilm, as recently described [35] and (Gützkow et al: A high throughput comet assay using 96 A high throughput comet assay using 96 minigelsminigels, in preparation). BAL cell suspensions in freezing medium with $10 \%$ DMSO were thawed quickly. For liver, deep frozen samples (ca. $40 \mathrm{mg}$ ) were pressed through a metal stapler (diameter $0.5 \mathrm{~cm}$, mesh size 0.4 $\mathrm{mm})$ into Merchant's media (0.14 M NaCl, $1.47 \mathrm{mM}$ $\mathrm{KH}_{2} \mathrm{PO} 4,2.7 \mathrm{mM} \mathrm{KCl}, 8.1 \mathrm{mM} \mathrm{Na}{ }_{2} \mathrm{HPO}_{4}, 10 \mathrm{mM}$ 
NaEDTA, pH 7.4) for inhibiting endogenous DNA cleaving enzymes (first described by [44])). Samples were embedded in agarose, lysed, subjected to alkaline electrophoresis, fixed and later stained and scored as previously described [35]. Due to preparation time, the lysing procedure varied between 1-3.5 hour for samples in the present study. In order to minimize the effects of this we normalized the results to the positive assay control. As a positive assay control and to estimate the electrophoresis-to-electrophoresis variation, 0 and $30 \mu \mathrm{M}$ $\mathrm{H}_{2} \mathrm{O}_{2}$ exposed A549 cells were included on each Gelbond film in all electrophoresis runs.

\section{Liver histology}

Specimens were taken from the liver of three to six mice from the vehicle control from the high dose groups of all test materials and euthanized 1, 3 or 28 days after instillation. The specimens were fixed in $4 \%$ neutral buffered formaldehyde, paraffin-embedded, and sections 4-6 $\mu \mathrm{m}$ were made and stained with hematoxylin and eosin for histological examination.

\section{Statistics}

The data were assessed by non-parametric three-way ANOVA with post-hoc Tukey-type multiple comparison test for effects showing statistical significance in the overall ANOVA test. Statistical significances were tested at $\mathrm{P}<0.05$ level. The statistical analyses were performed in SAS version 9.2 (SAS Institute Inc., Cary, NC, USA).

\section{Acknowledgements \\ The technical assistance from Lourdes Pedersen, Elzbieta Christiansen, Michael Guldbrandsen, Maria Hammer and Margit Wagtberg Frederiksen is gratefully acknowledged. The Danish Coatings and Adhesives Association and especially the following Danish paint companies kindly supplied the materials: Flügger, Beck\&ørgensen, Dyrup, Akzo Nobel, Teknos and Boesens Fabrikker. The research leading to these results has received funding from the Danish Working Environment Research Fund (Nanokem, grant \#20060068816) and the European Community's Seventh Framework Programme (FP7/2007-2013) under grant agreement n² 247989 (Nanosustain). The Comet analysis with the high throughput protocol was developed at Norwegian Institute of Public Health with the support of COMICS LSHB-CT-2006-037575.}

\section{Author details}

'The National Research Centre for the Working Environment, Lersø Parkallé 105, DK-2100 Copenhagen, Denmark. National Food Institute, Technical University of Denmark, Mørkhøj Bygade 19, DK-2860 Søborg, Denmark. ${ }^{3}$ University of Warmia and Mazury, Faculty of Veterinary Medicine, 10-719 Olsztyn, Poland. ${ }^{4}$ Department of Micro and Nanotechnology, Technical University of Denmark, DK-2800 Lyngby, Denmark. ${ }^{5}$ Institute of Public Health, University of Copenhagen, DK-1014 Copenhagen K, Denmark. ${ }^{6}$ Department of Chemical Toxicology, Division of Environmental Medicine, Norwegian Institute of Public Health, PO Box 4404 Nydalen, N-0403 Oslo, Norway.

\section{Authors' contributions}

HW, UV, NRJ and ATS were involved in the design of the study. IKK and KAJ generated the sanding dust. NRJ and ATS were involved in the design of the set-up of the mouse-exposure. AM and JS were responsible for the histological characterization. AMM carried out the endotoxin testing. HWA, NRJ, PJ, GB and KBG were responsible for the Comet assay. ATS was responsible for the toxicological data and submitted the manuscript. All authors approved the final manuscript.

\section{Competing interests}

The authors declare that they have no competing interests.

Received: 8 September 2011 Accepted: 2 February 2012

Published: 2 February 2012

\section{References}

1. Sepeur S: European Coatings Tech Files. Nanotoxicology: Technical Basics and Applications; Hannover. Vincentz Network 2008, ISBN:978-3-86630-9067, pp 5-168.

2. Baan RA: IARC Monographs on the Evaluation of Carcinogenic Risks to Humans. 2010, 93:193-214.

3. Johnston HJ, Hutchison GR, Christensen FM, Peters S, Hankin S, Stone V: Identification of the mechanisms that drive the toxicity of $\mathrm{TiO}(2)$ particulates: the contribution of physicochemical characteristics. Part Fibre Toxicol 2009, 6:33.

4. Schneider $T$, Jensen KA: Combined single drop and rotating drum dustiness test of fine to nanosized powders using a small drum. Annals of Occupational Hygiene 2008, 52:23-34.

5. Brouwer D: Exposure to manufactured nanoparticles in different workplaces. Toxicology 2010, 269:120-127.

6. Wohlleben W, Brill S, Meier MW, Mertler M, Cox G, Hirth S, von VB, Strauss V, Treumann S, Wiench K, Ma-Hock L, Landsiedel R: On the Lifecycle of Nanocomposites: Comparing Released Fragments and their In-Vivo Hazards from Three Release Mechanisms and Four Nanocomposites. Small 2011, doi:10.1002/smll.201002054.

7. Koponen IK, Jensen KA, Schneider T: Comparison of dust released from sanding conventional and nanoparticle-doped wall and wood coatings. J Expo Sci Environ Epidemiol 2011, 21:408-418.

8. Göhler D, Stintz M, Hillemann L, Vorbau M: Characterization of Nanoparticle Release from Surface Coatings by the Simulation of a Sanding process. Ann Occup Hyg 2010, 54:615-624.

9. Kaegi $R$, Ulrich $A$, Sinnet B, Vonbank R, Wichser A, Zuleeg S, Simmler H, Brunner S, Vonmont H, Burkhardt M, Boller M: Synthetic TiO2 nanoparticle emission from exterior facades into the aquatic environment. Environ Pollut 2008, 156:233-239.

10. Kaegi R, Sinnet B, Zuleeg S, Hagendorfer $H$, Mueller E, Vonbank R, Boller M, Burkhardt M: Release of silver nanoparticles from outdoor facades. Environ Pollut 2010, 158:2900-2905.

11. Oberdorster G, Oberdorster E, Oberdorster J: Nanotoxicology: an emerging discipline evolving from studies of ultrafine particles. Environ Health Perspect 2005, 113:823-839.

12. Saber AT, Koponen $\mathbb{I K}$, Jensen KA, Jacobsen NR, Mikkelsen $L$, Moller $P$ Loft S, Vogel U, Wallin H: Inflammatory and genotoxic effects of sanding dust generated from nanoparticle-containing paints and lacquers. Nanotoxicology 2011, DOI:10.3109/17435390.2011.620745.

13. Mikkelsen L, Jensen KA, Koponen IK, Saber AT, Wallin H, Loft S, Vogel U, Møller P: Cytotoxicity, oxidative stress and expression of adhesion molecules in human umbilical vein endothelial cells exposed to dust from paintswith or without nanoparticles. Nanotoxicology , (DOl:10 3109/ 174353902011 641604) 2011.

14. Saber AT, Jensen KA, Jacobsen NR, Birkedal R, Mikkelsen L, Moller P, Loft S, Wallin $\mathrm{H}$, Vogel U: Inflammatory and genotoxic effects of nanoparticles designed for inclusion in paints and lacquers. Nanotoxicology 2011, DOl:10.3109/17435390.2011.587900.

15. Jacobsen NR, Pojana G, White P, Moller P, Cohn CA, Korsholm KS, Vogel U, Marcomini A, Loft S, Wallin H: Genotoxicity, cytotoxicity, and reactive oxygen species induced by single-walled carbon nanotubes and $C(60)$ fullerenes in the FE1-Mutatrade markMouse lung epithelial cells. Environ Mol Mutagen 2008, 49:476-487.

16. Jacobsen NR, Saber AT, White P, Moller P, Pojana G, Vogel U, Loft S Gingerich J, Soper L, Douglas GR, Wallin H: Increased mutant frequency by carbon black, but not quartz, in the lacZ and cll transgenes of muta mouse lung epithelial cells. Environ Mol Mutagen 2007, 48:451-461.

17. Aschberger K, Johnston HJ, Stone V, Aitken RJ, Hankin SM, Peters SA, Tran CL, Christensen FM: Review of carbon nanotubes toxicity and exposure-appraisal of human health risk assessment based on open literature. Crit Rev Toxicol 2010, 40:759-790. 
18. Sharma AK, Wallin H, Jensen KA: High volume electrostatic field-sampler for collection of fine particle bulk samples. Atmospheric Environment 2007, 41:369-381.

19. Bourdon JA, Saber AT, Jacobsen NR, Jensen KA, Madsen AM, Lamson JS, Wallin H, Møller P, Loft S, Yauk C, Vogel U: Carbon Black Nanoparticle Instillation Induces Sustained Inflammation and Genotoxicity in Mouse Lung and Liver. Particle and Fibre Toxicology

20. Hougaard KS, Jackson P, Jensen KA, Sloth JJ, Loschner K, Larsen EH, Birkedal RK, Vibenholt A, Boisen AM, Wallin $\mathrm{H}$, Vogel U: Effects of prenatal exposure to surface-coated nanosized titanium dioxide (UV-Titan). A study in mice. Part Fibre Toxicol 2010, 7:16.

21. Dybing E, Sanner T, Roelfzema H, Kroese D, Tennant RW: T25: a simplified carcinogenic potency index: description of the system and study of correlations between carcinogenic potency and species/site specificity and mutagenicity. Pharmacol Toxicol 1997, 80:272-279.

22. Baan RA: Carcinogenic hazards from inhaled carbon black, titanium dioxide, and talc not containing asbestos or asbestiform fibers: recent evaluations by an IARC Monographs Working Group. Inhal Toxicol 2007, 19(Suppl 1):213-228.

23. Tran $C L$, Buchanan $D$, Cullen RT, Searl A, Jones AD, Donaldson K: Inhalation of poorly soluble particles. II. Influence Of particle surface area on inflammation and clearance. Inhal Toxicol 2000, 12:1113-1126.

24. Donaldson K, Brown D, Clouter A, Duffin R, MacNee W, Renwick L, Tran L, Stone V: The pulmonary toxicology of ultrafine particles. J Aerosol Med 2002, 15:213-220.

25. Gilmour PS, Ziesenis A, Morrison ER, Vickers MA, Drost EM, Ford I, Karg E, Mossa C, Schroeppel A, Ferron GA, Heyder J, Greaves M, MacNee W, Donaldson K: Pulmonary and systemic effects of short-term inhalation exposure to ultrafine carbon black particles. Toxicol Appl Pharmacol 2004, 195:35-44.

26. Jacobsen NR, Moller $\mathrm{P}$, Jensen $\mathrm{KA}$, Vogel $\mathrm{U}$, Ladefoged $\mathrm{O}$, Loft $\mathrm{S}$, Wallin $\mathrm{H}$ : Lung inflammation and genotoxicity following pulmonary exposure to nanoparticles in ApoE-/- mice. Part Fibre Toxicol 2009, 6:2.

27. Stoeger T, Reinhard C, Takenaka S, Schroeppel A, Karg E, Ritter B, Heyder J, Schulz H: Instillation of six different ultrafine carbon particles indicates a surface area threshold dose for acute lung inflammation in mice. Environ Health Perspect 2006, 114:328-333.

28. Shvedova AA, Kisin ER, Murray AR, Kommineni C, Castranova V, Fadeel B, Kagan VE: Increased accumulation of neutrophils and decreased fibrosis in the lung of NADPH oxidase-deficient C57BL/6 mice exposed to carbon nanotubes. Toxicol Appl Pharmacol 2008, 231:235-240.

29. Park EJ, Roh J, Kim SN, Kang MS, Han YA, Kim Y, Hong JT, Choi K: A single intratracheal instillation of single-walled carbon nanotubes induced early lung fibrosis and subchronic tissue damage in mice. Arch Toxicol 2011.

30. Kamata H, Tasaka S, Inoue K, Miyamoto K, Nakano Y, Shinoda H, Kimizuka Y, Fujiwara H, Ishii M, Hasegawa N, Takamiya R, Fujishima S, Takano H, Ishizaka A: Carbon black nanoparticles enhance bleomycin-induced lung inflammatory and fibrotic changes in mice. Exp Biol Med (Maywood) 2011, 236:315-324.

31. Brass DM, Yang IV, Kennedy MP, Whitehead GS, Rutledge H, Burch LH, Schwartz DA: Fibroproliferation in LPS-induced airway remodeling and bleomycin-induced fibrosis share common patterns of gene expression. Immunogenetics 2008, 60:353-369.

32. Bornholdt J, Dybdahl M, Vogel U, Hansen M, Loft S, Wallin H: Inhalation of ozone induces DNA strand breaks and inflammation in mice. Mutat Res 2002, 520:63-71.

33. Kostka G, Palut D, Kopec-Szlezak J, Ludwicki JK: Early hepatic changes in rats induced by permethrin in comparison with DDT. Toxicology 2000, 142:135-143.

34. Takanori Harada, Akiko Enomoto, Boorman AGary, Maronpot RRobert: Chapter 7: Liver and gallbladder. 1999, 1:122.

35. Jackson $\mathrm{P}$, Hougaard KS, Boisen AM, Jacobsen NR, Jensen KA, Moller $\mathrm{P}$, Brunborg G, Gutzkow KB, Andersen O, Loft S, Vogel U, Wallin H: Pulmonary exposure to carbon black by inhalation or instillation in pregnant mice: Effects on liver DNA strand breaks in dams and offspring. Nanotoxicology 2011.

36. Sung JH, Ji JH, Park JD, Yoon JU, Kim DS, Jeon KS, Song MY, Jeong J, Han BS, Han JH, Chung YH, Chang HK, Lee JH, Cho MH, Kelman BJ, Yu IJ: Subchronic inhalation toxicity of silver nanoparticles. Toxicol Sci 2009, 108:452-461.
37. Ji JH, Jung JH, Kim SS, Yoon JU, Park JD, Choi BS, Chung YH, Kwon $\mathbb{H}_{\text {, }}$ Jeong J, Han BS, Shin JH, Sung JH, Song KS, Yu IJ: Twenty-eight-day inhalation toxicity study of silver nanoparticles in Sprague-Dawley rats. Inhal Toxicol 2007, 19:857-871.

38. Saber AT, Bornholdt J, Dybdahl M, Sharma AK, Loft S, Vogel U, Wallin H: Tumor necrosis factor is not required for particle-induced genotoxicity and pulmonary inflammation. Arch Toxicol 2005, 79:177-182.

39. Saber AT, Halappanavar S, Folkmann JK, Bornholdt J, Boisen AM, Moller P, Williams A, Yauk C, Vogel U, Loft S, Wallin H: Lack of acute phase response in the livers of mice exposed to diesel exhaust particles or carbon black by inhalation. Part Fibre Toxicol 2009, 6:12.

40. Dybdahl M, Risom L, Bornholdt J, Autrup H, Loft S, Wallin H: Inflammatory and genotoxic effects of diesel particles in vitro and in vivo. Mutat Res 2004, 562:119-131.

41. Bornholdt J, Saber AT, Sharma AK, Savolainen K, Vogel U, Wallin H: Inflammatory response and genotoxicity of seven wood dusts in the human epithelial cell line A549. Mutat Res 2007, 632:78-88.

42. McNamee JP, McLean JR, Ferrarotto CL, Bellier PV: Comet assay: rapid processing of multiple samples. Mutat Res 2000, 466:63-69.

43. Collins AR: Investigating oxidative DNA damage and its repair using the comet assay. Mutat Res 2009, 681:24-32.

44. Kinley JS, Brunborg G, Moan J, Young AR: Detection of UVR-induced DNA damage in mouse epidermis in vivo using alkaline elution. Photochem Photobiol 1995, 61:149-158.

doi:10.1186/1743-8977-9-4

Cite this article as: Saber et al: Nanotitanium dioxide toxicity in mouse lung is reduced in sanding dust from paint. Particle and Fibre Toxicology 2012 9:4.

\section{Submit your next manuscript to BioMed Central and take full advantage of:}

- Convenient online submission

- Thorough peer review

- No space constraints or color figure charges

- Immediate publication on acceptance

- Inclusion in PubMed, CAS, Scopus and Google Scholar

- Research which is freely available for redistribution 